\title{
PENGARUH RASIO LEVERAGE DAN KEPEMILIKAN PUBLIK TERHADAP KETEPATAN WAKTU PELAPORAN KEUANGAN PADA PERUSAHAAN MANUFAKTUR YANG TERDAFTAR DI BURSA EFEK INDONESIA
}

\author{
Yan Christin Br. Sembiring
}

\begin{abstract}
Abstrak
Tujuan penelitian ini adalah untuk menguji secara empiris pengaruh rasio leverage dan kepemilikan publik terhadap ketepatan waktu pelaporan keuangan pada perusahaan manufaktur yang terdaftar di Bursa Efek Indonesia secara simultan dan parsial. Populasi dalam penelitian ini diambil dari perusahaan manufaktur yang terdaftar di Bursa Efek Indonesia selama tahun 2010-2012 yaitu 131 perusahaan. Adapun metode yang digunakan adalah metode purposive sample dimana perusahaan yang masuk dalam kriteria adalah berjumlah 75 perusahaan. Data diolah dengan menggunakan uji statistik regresi logistik. Hasil penelitian ini menyimpulkan bahwa leverage dan kepemilikan publik berpengaruh signifikan terhadap ketepatan waktu pelaporan keuangan secara simultan. Secara parsial hanya variabel kepemilikan publik yang berpengaruh signifikan terhadap ketepatan waktu pelaporan keuangan.
\end{abstract}

Kata kunci : Leverage, Kepemilikan Publik, dan Ketepatan Waktu Pelaporan Keuangan

\section{PENDAHULUAN}

Perkembangan pasar modal di Indonesia menyebabkan adanya permintaan akan transparansi kondisi keuangan perusahaan. Laporan keuangan disusun dan disajikan sekurang-kurangnya sekali dalam setahun untuk memenuhi kebutuhan para pengguna, misalkan sebelum memutuskan untuk berinvestasi di Bursa Efek Indonesia, investor memerlukan informasi laporan keuangan perusahaan Tbk yang diterbitkan. Ketepatan waktu merupakan salah satu elemen pokok dalam laporan keuangan tersebut. Manfaat suatu laporan keuangan akan berkurang jika laporan tersebut tidak tersedia tepat pada waktunya (IAI, 2007). Ketepatan waktu pelaporan keuangan dapat mempengaruhi nilai informasi suatu laporan keuangan. Informasi akan bermanfaat jika disampaikan tepat waktu. Informasi yang disajikan tidak tepat waktu dapat mengurangi, bahkan menghilangkan kemampuan laporan keuangan sebagai alat bantu prediksi bagi pengguna.

Perusahaan-perusahaan yang terdaftar di Bursa Efek Indonesia wajib menyampaikan laporan keuangan secara berkala kepada Badan Pengawas Pasar Modal-Lembaga Keuangan (Bapepam-LK) dan mengumumkan pada 
masyarakat untuk memenuhi prinsip keterbukaan sesuai dengan pasal 86 ayat 1 Undang-Undang Nomor 8 Tahun 1995 tentang pasar modal. Tuntutan akan ketepatan waktu penyampaian laporan keuangannya diatur dalam Keputusan Ketua Badan Pengawas Pasar Modal Nomor 36/PM/2003 tentang Kewajiban Penyampaian Laporan Keuangan Berkala dengan Nomor Peraturan X.K.2 yaitu paling lambat akhir bulan ketiga setelah tanggal laporan keuangan tahunan. Perusahaan publik yang tidak dapat menyampaikan laporan keuangan tahunan sesuai aturan akan dikenakan sanksi mulai dari peringatan hingga suspensi, dan apabila terlambat menyampaikan laporan keuangan akan dikenakan sanksi administratif berupa denda paling banyak Rp 500.000.000.

Regulasi yang dibuat seharusnya memacu perusahaan publik untuk menyampaikan laporan keuangan tahunan tepat waktu. Fenomena yang terjadi pada kenyataannya setiap tahun ketepatan waktu pelaporan keuangan mengalami penurunan, sementara regulasi yang berlaku pada periode tersebut masih sama dan belum mengalami perubahan. Fenomena tersebut menunjukkan bahwa regulasi tidak dapat menjadi satu-satunya faktor yang mempengaruhi perusahaan publik menyampaikan laporan keuangan tepat waktu di setiap periode. Oleh karena itu, perlu diperhatikan lebih jauh faktor-faktor lain yang dapat mempengaruhi ketepatan waktu pelaporan keuangan, seperti profitabilitas dan likuiditas.

Leverage mengacu pada seberapa jauh suatu perusahaan bergantung pada kreditor dalam membiayai aktiva perusahaan. Leverage keuangan dapat diartikan sebagai penggunaan aset dan sumber dana oleh perusahaan yang memiliki biaya tetap dengan maksud meningkatkan keuntungan potensial pemegang saham. Suatu perusahaan yang memiliki leverage keuangan yang tinggi berarti memiliki banyak hutang pada pihak luar. Ini berarti perusahaan tersebut memiliki risiko keuangan yang tinggi karena mengalami kesulitan keuangan (financial distress) akibat hutang yang tinggi. Perusahaan yang mengalami kesulitan keuangan cenderung tidak tepat waktu dalam menyampaikan laporan keuangannya dibanding perusahaan yang tidak mengalami kesulitan keuangan. Kesulitan keuangan juga merupakan berita buruk sehingga perusahaan dengan kondisi seperti ini cenderung tidak tepat waktu dalam pelaporan keuangannya. Akan tetapi, dalam penelitian Hilmi (2007) dinyatakan bahwa leverage tidak berpengaruh signifikan terhadap ketepatan waktu pelaporan keuangan.

Kepemilikan publik adalah kepemilikan masyarakat umum terhadap saham perusahaan publik. Kepemilikan perusahaan oleh pihak luar mempunyai kekuatan yang besar dalam mempengaruhi perusahaan melalui 
media massa berupa kritikan atau komentar yang semuanya dianggap suara publik atau masyarakat. Adanya kosentrasi kepemilikan pihak luar menimbulkan pengaruh dari pihak luar sehingga mengubah pengelolaan perusahaan yang semula berjalan sesuai keinginan perusahaan itu sendiri menjadi memiliki keterbatasan. Dengan demikian, perusahaan dengan proporsi kepemilikan publik yang besar cenderung tepat waktu dalam pelaporan keuangannya. Penelitian Hilmi (2007) menyatakan bahwa kepemilikan publik berpengaruh signifikan terhadap ketepatan waktu pelaporan keuangan.

Berdasarkan uraian tersebut, maka peneliti tertarik untuk melakukan penelitian lebih lanjut dengan judul penelitian "Pengaruh Rasio Leverage dan Kepemilikan Publik Terhadap Ketepatan Waktu Pelaporan Keuangan Pada Perusahaan Manufaktur yang Terdaftar di Bursa Efek Indonesia”

\section{TELAAH TEORI}

\section{Telaah Teori}

\section{a. Laporan Keuangan}

Tujuan laporan keuangan adalah menyediakan informasi yang menyangkut posisi keuangan, kinerja, serta perubahan posisi keuangan suatu perusahaan yang bermanfaat bagi sejumlah besar pengguna dalam pengambilan keputusan ekonomi (IAI, 2007). Pelaporan keuangan hendaknya memberikan informasi yang berguna bagi para calon investor dan kreditor, maupun yang sudah ada, dan para pengguna lainnya dalam membuat investasi, kredit, dan keputusan-keputusan lain yang serupa secara rasional (Riahi dan Belkaoui, 2006:233). Pelaporan keuangan merupakan salah satu sumber informasi yang mengkomunikasikan keadaan keuangan dari hasil operasi suatu perusahaan dalam periode tertentu kepada pihak-pihak yang berkepentingan.

\section{b. Teori Kepatuhan}

Berdasarkan Pernyataan Standar Akuntansi Keuangan (PSAK) Nomor 1 paragraf 38, suatu perusahaan sebaiknya mengeluarkan laporan keuangannya paling lama 4 (empat) bulan setelah tanggal neraca (IAI, 2007). Perusahaan publik yang terdaftar di Bursa Efek Indonesia dituntut untuk mematuhi peraturan berdasarkan Keputusan Ketua Badan Pengawas Pasar Modal (Bapepam) Nomor 36/PM/2003, tentang Kewajiban Penyampaian Laporan Keuangan Berkala yang diaudit dengan Nomor Peraturan X.K.2, yaitu laporan keuangan tahunan harus disertai dengan laporan akuntan dengan pendapat yang lazim dan disampaikan kepada 
Badan Pengawas Pasar Modal (Bapepam) selambat-lambatnya pada akhir bulan ketiga setelah tanggal laporan keuangan tahunan. Laporan keuangan disusun berdasarkan prinsip akuntansi yang berlaku umum yang pada pokoknya adalah Standar Akuntansi Keuangan yang ditetapkan oleh Ikatan Akuntan Indonesia (IAI) dan ketentuan akuntansi di bidang pasar modal yang ditetapkan Badan Pengawas Pasar Modal (Bapepam).

\section{c. Ketepatan Waktu Pelaporan Keuangan}

Tepat waktu diartikan bahwa informasi harus disampaikan sedini mungkin agar dapat digunakan sebagai dasar dalam pengambilan keputusan ekonomi dan untuk menghindari tertundanya pengambilan keputusan tersebut (Rachmawati, 2008). Berdasarkan Kerangka Dasar Penyusunan dan Penyajian Laporan Keuangan paragraf 24 (IAI, 2007) laporan keuangan harus memenuhi empat karakteristik kualitatif yang merupakan ciri khas yang membuat informasi laporan keuangan berguna bagi para pengguna. Keempat karakterisktik tersebut yaitu dapat dipahami, relevan, keandalan, dan dapat dibandingkan. Paragraf 43 (IAI, 2007) menyatakan bahwa tepat waktu merupakan salah satu kendala informasi yang relevan dan andal, dan jika terdapat penundaan yang tidak semestinya dalam pelaporan, maka informasi yang dihasilkan akan kehilangan relevansinya. Manajemen mungkin perlu menyeimbangkan manfaat relatif antara pelaporan tepat waktu dan ketentuan informasi andal. Untuk menyediakan informasi tepat waktu, sering kali perlu melaporkan sebelum seluruh aspek transaksi atau peristiwa lainnya diketahui, sehingga mengurangi keandalan informasi. Sebaliknya jika pelaporan ditunda sampai seluruh aspek diketahui, informasi yang dihasilkan mungkin sangat andal tetapi kurang bermanfaat bagi pengambil keputusan. Dalam usaha mencapai keseimbangan antara relevansi dan keandalan, kebutuhan pengambil keputusan merupakan pertimbangan yang menentukan.

\section{d. Leverage}

Suatu perusahaan yang memiliki leverage keuangan yang tinggi berarti memiliki banyak hutang pada pihak luar. Ini berarti perusahaan tersebut memiliki risiko keuangan yang tinggi karena mengalami kesulitan keuangan (financial distress) akibat hutang yang tinggi. Perusahaan yang mengalami kesulitan keuangan cenderung tidak tepat waktu dalam menyampaikan laporan keuangannya dibanding perusahaan yang tidak mengalami kesulitan keuangan. Kesulitan keuangan juga merupakan berita buruk (bad news) sehingga perusahaan dengan kondisi seperti ini 
cenderung tidak tepat waktu dalam pelaporan keuangannya. Dalam penelitian menggunakan long debt to equity ratio (LDER) dengan rumus sebagai berikut (Kadir, 2011):

$$
\text { LDER }=\frac{\text { Liabilitas Jangka Panjang }}{\text { Total Aset }}
$$

\section{e. Kepemilikan Publik}

Kepemilikan publik adalah kepemilikan masyarakat umum (bukan institusi yang signifikan) terhadap saham perusahaan publik. Suharli (2006) mengungkapkan bahwa struktur kepemilikan perusahaan dapat disebut juga sebagai struktur kepemilikan saham, yaitu suatu perbandingan antara jumlah saham yang dimiliki oleh pihak dalam atau manajemen perusahaan (insider ownership's) dengan jumlah saham yang dimiliki oleh pihak luar (outsider ownership's).

\section{Kerangka Konsep}

Kerangka konsep dibentuk untuk menunjukkan pengaruh variabel independen yaitu profitabilitas dan likuiditas terhadap variabel dependen yaitu ketepatan waktu pelaporan keuangan seperti gambar berikut:

Gambar 2.1. Kerangka Konsep

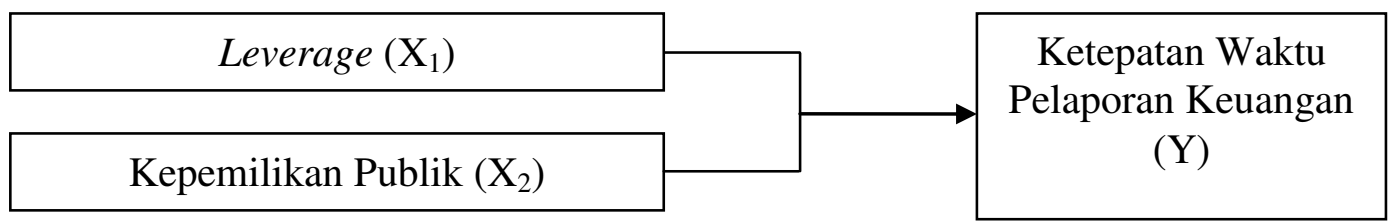

\section{Hipotesis}

Hipotesis merupakan jawaban sementara atas permasalahan dalam objek penelitian. Berdasarkan perumusan masalah, maka hipotesis penelitian ini adalah:

a. Rasio leverage berpengaruh terhadap ketepatan waktu pelaporan keuangan pada perusahaan manufaktur yang terdaftar di Bursa Efek Indonesia.

b. Kepemilikan publik berpengaruh terhadap ketepatan waktu pelaporan keuangan pada perusahaan manufaktur yang terdaftar di Bursa Efek Indonesia. 
c. Rasio leverage dan kepemilikan publik berpengaruh terhadap ketepatan waktu pelaporan keuangan pada perusahaan manufaktur yang terdaftar di Bursa Efek Indonesia.

\section{METODE PENELITIAN}

\section{Populasi dan Sampel}

Populasi dalam penelitian ini adalah seluruh perusahaan manufaktur yang terdaftar di Bursa Efek Indonesia selama tahun 2010-2012. Teknik penentuan sampel dalam penelitian ini yaitu menggunakan metode purposive sampling. Purposive sampling (sampling bertujuan) adalah metode pengambilan sampel berdasarkan suatu kriteria tertentu, kriteria yang digunakan dapat berdasarkan perimbangan (judgement) atau berdasarkan kuota tertentu (Erlina, 2011). Pengambilan sampel dalam penelitian ini dilakukan secara purposive sampling dengan tujuan mendapatkan sample yang representatif sesuai dengan kriteria yang telah ditentukan.

Dalam penelitian ini, kriteria perusahaan manufaktur yang dijadikan sampel penelitian adalah:

a. Perusahaan manufaktur yang menyampaikan laporan keuangan pada tahun 2010-2012 yang telah diaudit.

b. Perusahaan manufaktur yang menggunakan mata uang rupiah.

c. Perusahaan manufaktur dengan nilai ekuitas positif pada tahun 20102012.

Populasi dalam penelitian ini terdiri dari 131 perusahaan manufaktur. Populasi yang memenuhi kriteria untuk menjadi sampel berjumlah 75 perusahaan.

\section{Operasionalisasi Variabel}

Operasionalisasi variabel merupakan batasan pokok pembahasan yang akan diteliti. Variabel yang diteliti dalam penelitian ini adalah:

Leverage keuangan dapat diartikan sebagai penggunaan aset dan sumber dana oleh perusahaan yang memiliki biaya tetap dengan maksud meningkatkan keuntungan potensial pemegang saham. Leverage yang diproksikan dengan LDER dalam penelitian ini diukur dengan rumus sebagai berikut:

$$
\text { LDER }=\frac{\text { Liabilitas Jangka Panjang }}{\text { Total Aset }}
$$


Kepemilikan publik adalah kepemilikan masyarakat umum terhadap perusahaan publik. Variabel ini diukur dengan menghitung persentase jumlah saham yang dimiliki masyarakat umum dari seluruh modal saham yang beredar.

Dalam penelitian ini variabel dependen adalah ketepatan waktu pelaporan keuangan. Variabel ini diukur dengan menggunakan variabel dummy dimana angka 1 diberikan jika perusahaan menyampaikan laporan keuangan tepat waktu, yakni paling lambat akhir bulan ketiga setelah tanggal laporan keuangan tahunan dan angka 0 diberikan jika perusahaan menyampaikan laporan keuangan tidak tepat waktu, yakni setelah akhir bulan ketiga setelah tanggal laporan keuangan tahunan.

\section{Teknik Analisis Data}

Penelitian ini menggunakan metode analisis data regresi logistik. Model ini memungkinkan estimasi persamaan regresi yang dapat menjaga agar hasil prediksi variabel dependennya tetap berada di rentang nilai 0 dan 1. Secara praktis, model diformulasikan sebagai persamaan:

$\operatorname{Ln}\left[\operatorname{odds}\left(\mathrm{Xi}_{1-5}\right)\right]=\mathrm{b} 0+\mathrm{b} 1 \mathrm{x} 1+\mathrm{b} 2 \mathrm{x} 2$

atau

$$
\operatorname{Ln} \frac{p}{1-p}=b 0+b 1 \times 1+b 2 \times 2+e
$$

Di mana:

$$
\operatorname{odds}\left(\mathrm{Xi}_{1-4}\right)=\frac{\mathrm{p}}{1-\mathrm{p}}
$$

Keterangan:

$\mathrm{p}=$ probabilitas ketepatan waktu pelaporan keuangan, di mana:

$1=$ untuk perusahaan yang tepat waktu

$0=$ untuk perusahaan yang tidak tepat waktu

Dengan variabel bebas (Xi) :

$\mathrm{x}_{1}=$ leverage

$\mathrm{x}_{2}=$ kepemilikan publik

\section{HASIL PENELITIAN DAN PEMBAHASAN}

\section{Uji Asumsi Klasik}

Regresi yang baik adalah regresi dengan tidak adanya gejala korelasi yang kuat antara variabel bebasnya. Multikolinearitas adalah situasi adanya korelasi antara variabel-variabel independen antara yang satu dengan yang 
lainnya. Metode yang digunakan untuk mendeteksi multikolinearitas dalam penelitian ini adalah tolerance - Variance Inflector Factor (VIF). Multikolinearitas terjadi apabila nilai VIF $\geq 10$ dan nilai tolerance $\leq 0,10$ (Ghozali, 2009). Hasil olah data dapat dilihat dari tabel berikut ini:

\section{Tabel 4.1 Hasil Uji Multikolinearitas}

Coefficients $^{\mathrm{a}}$

\begin{tabular}{|c|c|c|c|c|c|c|c|}
\hline \multirow[t]{2}{*}{ Model } & \multicolumn{2}{|c|}{$\begin{array}{c}\text { Unstandardized } \\
\text { Coefficients }\end{array}$} & \multirow{2}{*}{$\begin{array}{c}\begin{array}{c}\text { Standardized } \\
\text { Coefficients }\end{array} \\
\text { Beta }\end{array}$} & \multirow[b]{2}{*}{$\mathrm{t}$} & \multirow[b]{2}{*}{ Sig. } & \multicolumn{2}{|c|}{ Collinearity Statistics } \\
\hline & $\mathrm{B}$ & Std. Error & & & & Tolerance & VIF \\
\hline $1 \quad$ (Constant) & 1.056 & .037 & & 28.417 & .000 & & \\
\hline Lev & -.075 & .058 & -.084 & -1.288 & .199 & .952 & 1.050 \\
\hline $\mathrm{KP}$ & -.005 & .001 & -.278 & -4.249 & .000 & .952 & 1.050 \\
\hline
\end{tabular}

a. Dependent Variable: KWPK

Sumber Hasil Penelitian, 2014 (data diolah SPSS 18)

Dari Tabel 4.1 menunjukkan hasil perhitungan nilai tolerance tidak ada variabel independen yang memiliki nilai tolerance yang kurang dari 0,10 yang berarti tidak ada korelasi antarvariabel independen yang nilainya lebih dari $95 \%$. Hasil perhitungan nilai VIF juga menunjukkan hal yang sama tidak ada satu variabel independen yang memiliki nilai VIF lebih dari 10. Jadi dapat disimpulkan bahwa tidak ada multikolinearitas antarvariabel independen dalam model regresi.

Menurut Ghozali (2009) uji autokorelasi bertujuan menguji apakah dalam suatu model regresi linear ada korelasi antara kesalahan pengganggu pada periode $\mathrm{t}$ dengan kesalahan pada periode $\mathrm{t}_{-1}$ (sebelumnya). Jika terjadi korelasi, maka dinamakan ada masalah autokorelasi. Autokorelasi muncul karena observasi yang berurutan sepanjang waktu berkaitan satu sama lain. Masalah ini timbul karena residual (kesalahan pengganggu) tidak bebas dari satu observasi ke observasi lainnya. Hal ini sering ditemukan pada data runtut waktu atau time series karena "gangguan" pada individu atau kelompok cenderung mempengaruhi individu atau kelompok pada periode berikutnya. Model regresi yang baik adalah regresi yang bebas dari autokorelasi.

Pada penelitian ini, gejala autokorelasi dideteksi dengan menggunakan uji Durbin Watson atau DW-statistic. Kriteria pengambilan keputusan adalah jika du $\leq \mathrm{DW} \leq 4,00-\mathrm{du}$, berarti tidak terdapat gejala autokorelasi pada model tersebut. Hasil olah data dapat dilihat dari tabel berikut ini: 
Tabel 4.2 Hasil Uji Autokorelasi

Model Summary ${ }^{\mathrm{b}}$

\begin{tabular}{|l|r|r|r|r|r|}
\hline Model & $\mathrm{R}$ & $\mathrm{R}$ Square & $\begin{array}{c}\text { Adjusted R } \\
\text { Square }\end{array}$ & $\begin{array}{c}\text { Std. Error of the } \\
\text { Estimate }\end{array}$ & Durbin-Watson \\
\hline 1 & $.308^{\mathrm{a}}$ & .095 & .086 & .28451 & 2.095 \\
\hline
\end{tabular}

a. Predictors: (Constant), KP, Lev

b. Dependent Variable: KWPK

Sumber Hasil Penelitian, 2014 (data diolah SPSS 18)

Dari tabel 4.2 diketahui nilai DW sebesar 2,095. Kriteria pengujian adalah du $\leq \mathrm{DW} \leq 4,00-$ du. Nilai du sebesar 1.65, maka 1,65 $\leq 2,095 \leq$ 2,35 . Artinya tidak terjadi gejala autokorelasi pada model tersebut.

\section{Pengujian Hipotesis}

a. Uji Kesesuaian Model/Goodness of Fit Test (Hosmer and Lemeshow)

Menurut Ghozali (2009) Hosmer and Lemeshow's Goodness of Fit

Test digunakan untuk menguji hipotesis nol bahwa data empiris cocok atau sesuai dengan model (tidak ada perbedaan antara model dengan data sehingga dapat dikatakan fit). Jika nilai Hosmer and Lemeshow's Goodness of Fit Test $\leq$ 0,05, maka hipotesis nol ditolak yang berarti ada perbedaan signifikan antara model dengan nilai observasinya sehingga Goodness of Fit Test model tidak baik karena model tidak dapat memprediksi nilai observasinya. Jika nilai statistik Hosmer and Lemeshow's Goodness of Fit Test $>0,05$ maka hipotesis nol tidak dapat ditolak dan berarti model mampu memprediksi nilai observasi atau dapat dikatakan model dapat diterima karena cocok dengan data observasinya.

Tabel 5.1 Hosmer and Lemeshow's Goodness of Fit Test Hosmer and Lemeshow Test

\begin{tabular}{|l|r|r|r|}
\hline Step & Chi-square & \multicolumn{1}{|c|}{ Df } & Sig. \\
\hline 1 & 11.972 & & .152 \\
\hline
\end{tabular}

Sumber Hasil Penelitian, 2014 (data diolah SPSS 18)

Dari Tabel 5.1 tersebut, hasil output SPSS menunjukkan bahwa besarnya nilai statistik Hosmer and Lemeshow's Goodness of Fit Test sebesar 11,972 dengan probabilitas signifikansi 0,152 yang nilainya di atas 0,05. Dengan demikian dapat disimpulkan bahwa model dapat diterima.

\section{b. Uji Omnibus (Uji G)}

Hasil pengujian hipotesis ini bertujuan untuk mengetahui apakah leverage dan kepemilikan publik berpengaruh secara simultan terhadap 
ketepatan waktu pelaporan keuangan perusahaan. Pengujian ini ditunjukkan dalam Tabel 5.2 berikut.

Tabel 5.2 Uji Omnibus Omnibus Tests of Model Coefficients

\begin{tabular}{|rl|r|r|r|}
\hline & & Chi-square & df & \multicolumn{1}{c|}{ Sig. } \\
\hline Step 1 & Step & 20.776 & 2 & .000 \\
& Block & 20.776 & 2 & .000 \\
& Model & 20.776 & 2 & .000 \\
\hline
\end{tabular}

Sumber : Hasil Penelitian, 2014 (data diolah SPSS 18)

Berdasarkan Tabel 5.2 tersebut dapat dilihat nilai signifikansi sebesar 0,000 adalah lebih kecil dari 0,05. Sehingga dapat disimpulkan bahwa variabel-variabel independen (profitabilitas dan likuiditas) berpengaruh secara simultan terhadap ketepatan waktu pelaporan keuangan perusahaan.

\section{c. Uji Koefisien Determinasi (Nagelkerke R Square)}

Nagelkerke $R$ Square merupakan modifikasi dari koefisien Cox dan Snell untuk memastikan bahwa nilainya bervariasi dari 0 (nol) sampai 1 (satu). Nilai Nagelkerke $R$ Square dapat diinterpretasikan seperti nilai $\mathrm{R}^{2}$ pada multiple regression (Ghozali, 2009). Pengujian ini ditunjukkan dalam Tabel 5.3 berikut.

Tabel 5.3 Uji Koefisien Determinasi Model Summary

\begin{tabular}{|l|r|r|r|}
\hline Step & -2 Log likelihood & $\begin{array}{c}\text { Cox \& Snell R } \\
\text { Square }\end{array}$ & $\begin{array}{c}\text { Nagelkerke R } \\
\text { Square }\end{array}$ \\
\hline 1 & $123.302^{\mathrm{a}}$ & .088 & .187 \\
\hline
\end{tabular}

a. Estimation terminated at iteration number 6 because parameter estimates changed by less than .001 .

Sumber : Hasil Penelitian, 2014 (data diolah SPSS 18)

Dari Tabel 5.3 dapat dilihat bahwa nilai koefisien determinasi regresi logistik sebesar 0,187. Hal ini dapat menunjukkan bahwa kontribusi nilai variabel independen terhadap variabel dependen adalah sebesar 0,187. Hal ini berarti variabilitas variabel dependen yang dapat dijelaskan oleh variabilitas variabel independen adalah sebesar 18,7\% dan sisanya oleh variabel yang lain. 


\section{d. Uji Wald}

Uji wald adalah pengujian koefisien regresi untuk mengetahui apakah masing-masing variabel independen yang dimasukkan dalam model mempunyai pengaruh terhadap variabel dependen (Ghozali, 2009). Koefisien regresi dapat ditentukan dengan menggunakan Wald Statistic dan nilai probabilitas (Sig.). Jika nilai Wald Statistic lebih besar dibandingkan Chi-Square dan nilai probabilitas (Sig.) lebih kecil dari 0,05 $(\alpha)$ berarti variabel independen berpengaruh secara parsial terhadap variabel dependen. Hasilnya terlihat pada Tabel 5.16 berikut.

Tabel 5.4 Uji Koefisien Regresi Logistik Variables in the Equation

\begin{tabular}{|rl|r|r|r|r|r|r|}
\hline & & \multicolumn{1}{|c|}{ B } & \multicolumn{1}{|c|}{ S.E. } & Wald & df & \multicolumn{1}{c|}{ Sig. } & \multicolumn{1}{c|}{$\operatorname{Exp}(\mathrm{B})$} \\
\hline Step $1^{\mathrm{a}}$ & Lev & -.680 & .574 & 1.404 & 1 & .236 & .506 \\
& KP & -.060 & .016 & 14.539 & 1 & .000 & .942 \\
& Constant & 4.436 & .671 & 43.720 & 1 & .000 & 84.398 \\
\hline
\end{tabular}

a. Variable(s) entered on step 1: Lev, KP.

Sumber : Hasil Penelitian, 2014 (data diolah SPSS 18)

Berdasarkan hasil pengujian dengan regresi logistik yang ditunjukkan pada Tabel 5.4 tersebut, maka diperoleh model regresi logistik sebagai berikut.

\section{$\operatorname{Ln}\left[\operatorname{odds}\left(\mathrm{Xi}_{1-5}\right)\right]=\mathbf{4 , 4 3 6}-\mathbf{0 , 6 8 0} \mathrm{Lev}-0,060 \mathrm{KP}$}

Konstanta sebesar 4,436 menyatakan bahwa jika tidak memperhitungkan leverage dan kepemilikan publik, maka kemungkinan ketepatan waktu pelaporan keuangan adalah sebesar 4,436.

Secara parsial, dari dua variabel yang dimasukkan ke dalam model regresi ada satu variabel yang berpengaruh signifikan terhadap ketepatan waktu pelaporan keuangan. Variabel tersebut adalah kepemilikan publik. Sedangkan variabel leverage tidak berpengaruh signifikan terhadap ketepatan waktu pelaporan keuangan.

\section{Pembahasan}

\section{a. Pengaruh Rasio Leverage terhadap Ketepatan Waktu Pelaporan Keuangan}

Hasil pengujian pada Tabel 5.4 menunjukkan bahwa variabel leverage tidak berpengaruh signifikan terhadap ketepatan waktu pelaporan keuangan. Hal ini dilihat dari tingkat signifikansi yang diperoleh sebesar 0,236 yang lebih besar dari $0,05(\alpha)$ dan koefisien yang diperoleh sebesar 0,680 9,398 yang artinya bahwa setiap kenaikan variabel profitabilitas 
sebesar $1 \%$, maka akan terjadi penurunan secara rata-rata estimasi logit sebesar 0,680 dengan asumsi variabel lain dianggap konstan. Nilai Exp (B) atau odds ratio yang diperoleh variabel ini sebesar 0,506 yang berarti bahwa setiap perusahaan yang mempunyai tingkat leverage lebih besar, cenderung akan tepat waktu menyampaikan laporan keuangan sebesar 0,506 kali dibandingkan dengan perusahaan dengan tingkat leverage yang lebih kecil. Hasil penelitian ini konsisten dengan penelitian Kadir (2011) yang menunjukkan bahwa leverage tidak berpengaruh signifikan terhadap ketepatan waktu pelaporan keuangan. Hal ini dikarenakan pada umumnya perusahaan dapat menyelesaikan permasalahan utang jangka panjangnya melalui proses restrukturisasi dengan pihak debitur. Kondisi tersebut dapat terjadi pada masa krisis ekonomi (pemulihan), sehingga permasalahan utang jangka panjang yang akan jatuh tempo bagi perusahaan masih dapat diselesaikan.

\section{b. Pengaruh Kepemilikan Publik terhadap Ketepatan Waktu Pelaporan Keuangan}

Hasil pengujian pada Tabel 5.4 menunjukkan bahwa variabel kepemilikan publik berpengaruh signifikan terhadap ketepatan waktu pelaporan keuangan. Hal ini dilihat dari tingkat signifikansi yang diperoleh sebesar 0,000 yang lebih kecil dari $0,05(\alpha)$ dan nilai odds ratio yang diperoleh variabel ini sebesar 0,942 yang berarti bahwa setiap perusahaan yang mempunyai rasio kepemilikan publik lebih tinggi, cenderung akan tepat waktu menyampaikan laporan keuangan sebesar 0,942 kali dibandingkan dengan perusahaan dengan rasio kepemilikan publiknya relatif rendah. Hasil penelitian ini tidak konsisten dengan penelitian Suharli dan Rachpriliani (2006) yang menunjukkan bahwa kepemilikan publik tidak berpengaruh signifikan terhadap ketepatan waktu pelaporan keuangan. Hal ini mengindikasikan bahwa persentase kepemilikan publik tidak terlalu mempunyai pengaruh yang kuat untuk mengawasi perusahaan dalam menyampaikan laporan keuangan secara tepat waktu. Akan tetapi, hasil penelitian ini mendukung hasil penelitian Hilmi dan Ali (2007) yang memperoleh hasil bahwa kepemilika publik berpengaruh signifikan terhadap ketepatan waktu pelaporan keuangan. Hal ini menunjukkan perusahaan kepemilikan publik mempunyai kekuatan yang besar dalam mempengaruhi perusahaan melalui media massa berupa kritikan atau komentar yang semuanya dianggap suara masyarakat. Dengan demikian, perusahaan cenderung tepat waktu dalam pelaporan keuangannya. 


\section{KESIMPULAN DAN SARAN}

\section{Kesimpulan}

Dari hasil penelitian analisis dan uji hipotesis yang telah dilakukan, peneliti mengambil kesimpulan sebagai berikut:

a. Ketepatan waktu pelaporan keuangan ternyata dari hasil penelitian dipengaruhi oleh leverage dan kepemilikan publik secara simultan.

b. Secara parsial kepemilikan publik berpengaruh signifikan terhadap ketepatan waktu pelaporan keuangan, sedangkan profitabilitas tidak berpengaruh signifikan terhadap ketepatan waktu pelaporan keuangan.

\section{Saran}

Dari kesimpulan yang telah diuraikan diatas, maka peneliti memiliki beberapa saran sebagai berikut:

a. Agar peneliti selanjutnya dapat menambah sampel perusahaan yang diteliti, jadi bukan hanya manufaktur saja.

b. Agar peneliti selanjutnya menambah periode pengamatan.

c. Agar peneliti selanjutnya menambah variabel independen yang akan diteliti, atau mengganti variabel yang tidak memiliki pengaruh dalam penelitian ini dengan variabel lainnya.

\section{DAFTAR PUSTAKA}

Dewi, Sofia Prima dan Jusia. 2013. "Faktor-faktor yang Mempengaruhi Ketepatan Waktu Penyampain Laporan Keuangan pada Perusahaan Real Estate dan Property yang Terdaftar di BEI". Jurnal Akuntansi, Volume 17 Nomor 3 hal 368-384, Universitas Tarumanegara. Jakarta.

Dyer, J., C., IV and A., J., McHugh. 1975. "Timeliness of the Australian Annual Report”. Journal of Accounting Research. Vol.13. No.2. pp.204-219.

Effendi. 2005. Manajemen Keuangan : Konsep, Aplikasi, Studi Kasus. Fama Utama, Jakarta.

Erlina. 2011. Metode Penelitian. P 87-88. Penerbit USU Press, Medan.

Fitri, Fauziana. 2013. "Faktor-faktor yang Mempengaruhi Ketepatan Waktu Penyampaian Laporan Keuangan". Jurnal Ilmiah, Volume 1 Nomor 2 hal 21-32, Universitas Bakrie. Jakarta.

Ghozali, Imam. 2009. Aplikasi Analisis Multivariate dengan Program IBM SPSS. Edisi V. Badan Penerbit UNDIP. Semarang. 
Hilmi, Utari dan Syaiful Ali. 2007. "Analisis Faktor-Faktor yang Mempengaruhi Ketepatan Waktu Penyampaian Laporan Keuangan (Studi Empiris Pada Perusahaan-Perusahaan Yang Terdaftar Di BEJ Periode 2004-2006)" Simposium Nasional Akuntansi XI.

Ikatan Akuntan Indonesia. 2007. Standar Profesional Akuntan Publik. Salemba Empat, Jakarta.

Kadir, Abdul. 2011. " Faktor-faktor yang Berpengaruh Terhadap Ketepatan Waktu Pelaporan Keuangan pada Perusahaan Manufaktur di BEJ". Jurnal Manajemen dan Akuntansi, Volume 12 Nomor 1 hal 1-12, Sekolah Tinggi Ilmu Ekonomi Indonesia, Banjarmasin.

Lubis, Fatma Ade dan Adi Syahputra. 2008. Pedoman Penulisan Proposal dan Tesis. Program Magister Akuntansi Sekolah Pasca Sarjana Universitas Sumatera Utara, Medan.

Mellyana, Dina dan Christina Dwi Astuti. 2005. "Pengaruh Profitabilitas Perusahaan Terhadap Ketepatan Waktu Pelaporan Keuangan". Jurnal Akuntansi, Volume 5 Nomor 3 hal 337-358, Universitas Trisakti, Jakarta.

Owusu, Stephen dan Ansah. 2000. "Timeliness of Corporate Financial Reporting in Emerging Capital Market: Empirical Evidence from The Zimbabwe Stock Exchange". Journal Accounting and Business Research. Vol.30. No.3. pp.241-254.

Putra, Pasca Dwi dan Roza Thohiri. 2013. "Analisis Faktor-faktor yang Mempengaruhi Ketepatan Waktu Pelaporan Keuangan pada Perusahaan yang Listing di BEI Periode 2008-2010”. Jurnal Bina Akuntansi, Volume 18 Nomor 1 hal 16-27, STIE IBBI, Medan.

Rachmawati, Sistya. 2008. "Pengaruh Faktor Internal dan Eksternal Perusahaan Terhadap Audit Delay dan Timeliness". Jurnal Akuntansi dan Keuangan, Volume 10 Nomor 1 hal 1-10, Universitas Indonesia, Jakarta.

Riahi, Ahmed dan Belkaoui. 2006. Teori Akuntansi, Edisi Kelima, Alih Bahasa: Yulianto, Ali Akbar, dan Risnawati Dermauli, Salemba Empat, Jilid 1, Jakarta.

Saleh, Rachmat. 2004, "Studi Empiris Ketepatan Waktu Pelaporan Keuangan Perusahaan Manufaktur di Bursa Efek Jakarta”, SNA VII, Bali.

Santoso, Rudy Tri. 1995, Prinsip Dasar Akuntansi Perbankan. Andi Offset, Yogyakarta. 
Soegeng, Soetedjo. 2006. "Faktor-faktor yang Mempengaruhi Audit Report Lag". Jurnal Ventura, Volume 9 Nomor 2 hal 77-92.

Suharli, Michell dan Awaliawati Rachpriliani. 2006. "Studi Empiris Faktor yang Berpengaruh Terhadap Ketepatan Waktu Pelaporan Keuangan”. Jurnal Bisnis dan Akuntansi. Volume 8 Nomor 1 hal 34-55, Universitas Katolik Atma Jaya, Jakarta.

Syafrudin, M. 2004. "Pengaruh Ketidaktepatwaktuan Penyampaian Laporan Keuangan pada Earning Response Coefficient: Stufi di Bursa Efek Jakarta”. Simposium Nasional Akuntansi VII.

Yusralaini, Restu Agusti, dan Livia Dara Raesya. 2010. “Analisis Faktorfaktor yang Mempengaruhi Ketepatan Waktu Penyampaian Laporan Keuangan Publik pada Perusahaan yang Terdaftar di BEI (2005-2007)". Jurnal Ekonomi. Volume 13 Nomor 2 hal 6-16, Universitas Riau, Pekanbaru. 